Relations industrielles

Industrial Relations

Gérard DION : Dictionnaire canadien des relations du travail. 2ième éd., Québec, Les Presses de l'Université Laval, 1986, 993

pp., ISBN 2-7637-6975-6

\title{
Alton W.J. Craig
}

Volume 41, numéro 3, 1986

URI : https://id.erudit.org/iderudit/050237ar

DOI : https://doi.org/10.7202/050237ar

Aller au sommaire du numéro

\section{Éditeur(s)}

Département des relations industrielles de l'Université Laval

\section{ISSN}

0034-379X (imprimé)

1703-8138 (numérique)

Découvrir la revue

Citer ce compte rendu

Craig, A. W. (1986). Compte rendu de [Gérard DION : Dictionnaire canadien des relations du travail. 2ième éd., Québec, Les Presses de l'Université Laval, 1986, 993 pp., ISBN 2-7637-6975-6]. Relations industrielles / Industrial Relations, 41(3), 644-646. https://doi.org/10.7202/050237ar

Tous droits réservés (C) Département des relations industrielles de l'Université Laval, 1986
Ce document est protégé par la loi sur le droit d'auteur. L'utilisation des services d'Érudit (y compris la reproduction) est assujettie à sa politique d'utilisation que vous pouvez consulter en ligne.

https://apropos.erudit.org/fr/usagers/politique-dutilisation/ 


\section{RECENSIONS BOOK REVIEWS}

Dictionnaire canadien des relations du travail, par Gérard Dion, deuxième édition, Québec, Les Presses de l'Université Laval, 1986, 1024 pp., ISBN 2-7637-6975-6

The second edition of this Dictionnaire represents an outstanding contribution to the literature on industrial relations in Canada, as well as a very useful reference work for students and practitioners of industrial relations in many parts of the world. This work places its author, Gérard Dion, in the company of the most distinguished scholars of industrial relations from the early writers in this emerging discipline to the greatest contemporary ones. This document will go down as one of the greatest and most enduring works in the annals of the history of industrial relations in Canada.

The second edition of this Dictionnaire includes a total of 19,442 French terms and their definitions. Many that were contained in the first edition have been revised and improved to make them more operational and over 2,550 new terms and their definitions have been added. The definitions range from fairly simple and straight forward ones to rather complex and lengthy ones, some of which take up more than one column of a two-column page. For example, the definition of the 'Conseil canadien des relations du travail - CCRT - Canada Labour relations Board - CLRB' (pp. 118-9) describes in detail the structure and functions of the CLRB. In discussing the evolution of this work with Dion over the years I learned that he has been so exacting in his choice of definitions that he often agonized for days over the most appropriate definition to use for particular terms.

Included also is an English-French index of 12,812 terms, thus making it a useful document for those of us who work in either one or both of these languages. A new and very useful addition to this edition is the inclusion of 600 Latin expressions which are translated into both French and English. This edition retains a number of appendices contained in the first edition, one of which is the titles of professional associations and their abbreviations (unions and government agencies) for North America as well as international and European organizations; and another contains union statistics for Canada as a whole and by province from 1911 to 1982 as well as union membership for the 10 largest Canadian cities for the period 1911 to 1982.

It also contains a detailed chronology of federal labour legislation in Canada from 1868 to 1982 and an equally detailed chronology for Québec from 1867 to 1985. In addition, it contains a chronology of important events in industrial in Canada from 1816 to 1985, in the United States from 1778 to 1985, in Great Britain from 1556 to 1985, in France from 1791 to 1984, and an international section from 1847 to 1984 . The enumeration of important events and personalities clearly demonstrates the breadth and depth of Gérard Dion's scholarship, and the enumerations could serve as the basis for a number of lectures on comparative union history and major world political developments and their implications for unionism and collective bargaining.

A new section on special ad hoc legislation enacted by the federal and provincial governments from 1950 to 1985 shows that Québec has made more frequent use of such legislation than any other jurisdiction in Canada. To all of the above information, this edition adds all of the recommendations and conventions of the ILO since its founding and specifies the conven- 
tions ratified by Canada. In addition, this edition contains the text of the Canadian Charter of Rights and Freedoms, and the Québec Charter of Human Rights and Freedoms. Hence the second edition is much more inclusive than the first one, both in terms of the greater number of terms and their definitions and other important information. While the author indicates in his "Introduction» that this work is not an «encyclopedie», it is certainly more than just a "dictionnaire» - although the latter constitutes the bulk of the book.

The preparation of the second edition took four years and, as the author indicates, he had the «naïveté» when he first started the project to estimate that it could be done in one year. When one compares the first and second editions, it is easy to see why the second edition took four years, and it must have been four-years of painstaking work. The greater exactitude of this edition makes it quite obvious why the preparation of the second edition took a considerable amount of time.

In my opinion every writer and practitioner in Canada should have a copy of this Dictionnaire in a very handy place on his/her book shelf. It is my understanding that since the first edition came out in 1976 there has been increasing uniformity of terminology in collective agreements in Québec, and the Dictionnaire often shows up during arbitration hearings. It is an indispensable work for any academic in Canada since many of our better articles are written in French, especially in this Journal.

The funding agencies which made the preparation and publication of this Dictionnaire possible invested their money wisely and with outstanding results. However, this work is such a valuable one for researchers and practitioners that it should be translated into English, and possibly other languages. The more precise our definitions across languages become, the more meaningful and useful will this document become. In my view, the ILO might be an appropriate agency to undertake such a task since the greater consistency of terminology that would result therefrom would greatly assist the world community of industrial relations scholars and practitioners.

Gérard Dion, now over 70 years of age, has received the highest distinctions that this country offers. He has received the Order of Canada decoration and he is the recipient of five honourary degrees from some of Canada's most prestigious universities. (Ironically enough, none of them is from a French-speaking university.) He is also a fellow of the Royal Society of Canada and in 1982 the Canadian Industrial Relations Association honoured him for his outstanding contribution to industrial relations in this country. He is still a professor emeritus at l'Université Laval and he has been involved as a teacher, researcher, and practitioner of industrial relations as a third-party neutral for practically his whole life. Being at Laval, he was fortunate to have had the facilities of the 'département des relations industrielles' at his disposal as well as outstanding colleagues to assist him with his work and with whom to test his ideas. Furthermore, he has had discussions with academics at other institutions, officials in the federal and provincial governments as well as with union and management officials. This great array of experts to whom the could turn for assistance indicates the respect that he has among members of the Canadian industrial relations community.

If Dion were to do nothing else in industrial relations, this Dictionnaire would be the crowning achievement to what he has already done and a monument to his life-long devotion as a teacher, researcher and practitioner of industrial relations. The Journal in which this review appears has been edited by him since 1947, and he is still the editor. While he and his colleagues at Laval have made this Journal one of the more outstanding ones on the world scene they are forever seeking ways to improve it. 
My first meeting with Abbé Dion, as his close friends affectionately refer to him, was at the annual meeting of the IRRA in Pittsburg in December 1962 when I was a graduate student at Cornell. At that time he had with him a copy of a brochure that contained a number of newspaper articles that he had written in which he was very critical of the «Duplessis» regime in Québec. The brochure also contained editorial comments on his articles from all across Canada. It is not by accident, then, that many of his students became active in the Québec trade union movement and in politics. However, no matter how important the work he is doing nor how high the circles in society in which he is able to operate, he is still as approachable as ever to neophytes like myself and to newcomers to our emerging discipline.

When Jean Sexton, Associate Editor of this Journal, asked me to write a review of Dion's Dictionnaire I agreed to do so with some hesitation since I had already received an autographed copy of it from Abbé Dion and I was aware of the critically important potential that this work could have. Also, my vocabulary of superlatives is rather limited for describing adequately this outstanding work. Nevertheless, I congratulate Abbé Dion most sincerely for providing us with this magnificent and most valuable work. I am confident that I express the sentiments of all of my English-speaking colleagues across Canada and elsewhere when I say «thank you most sincerely, Abbé Dion» for this masterpiece from which all of us will benefit immensely. We wish him continued success in his work in industrial relations and in the many other endeavours in which he is involved. Although we recognize his contribution and commitment to our «emerging discipline», we would like to see him take some time to enjoy his «retirement» - a retirement that is well deserved.

Alton W.J. CRAIG

University of Ottawa

Université d'Ottawa

Dictionnaire canadien des relations du travail, par Gérard Dion, Deuxième édition, Québec, Les Presses de l'Université Laval, 1986, xxviii - 993 pages. ISBN 2-7637-6975-6

Dès sa première parution, on le nommait déjà le «Dictionnaire Dion» - comme on dit le Larousse ou le Robert - et plusieurs ne savent même pas son vrai titre, cité en rubrique. Tout de suite, il est devenu un instrument indispensable, pour les étudiants comme pour les praticiens des relations du travail.

Pourquoi la deuxième édition exige-t-elle un compte rendu si élaboré? D'abord parce qu'elle contient $50 \%$ plus de pages, $50 \%$ plus de termes et $50 \%$ plus d'informations encyclopédiques, ce qui en fait un outil encore plus précieux, presque un nouvel ouvrage, dix ans après la publication de la première édition.

Même dans les domaines du droit et des rapports collectifs, qui étaient déjà particulièrement choyés dans la première édition, l'auteur apporte des compléments; il comble certains vides, en incluant des termes et des expressions juridiques comme les suivantes: appel accueilli et appelant (p. 27), irrecevabilité (268), recomptage judiciaire (391); dans le secteur des institutions: accord préliminaire et accord «sur la gueule» (8), préavis de licenciement, individuel et collectif (359); dans l'administration du personnel: absence fortuite et absence justifiée (3), appariement des emplois (27), échelon de poste et de salaire (77).

À part les compléments de ce genre, la plupart des additions reflètent soit des réalités nouvelles dans les relations du travail, soit leur généralisation: abattement de salaire "wage cut» 